УДК 342.9

DOI https://doi.org/10.32837/pyuv.v0i2(31).581

\author{
Ю. Ю. Швеив \\ orcid.org/0000-0002-6557-1416 \\ кандидат економічних наук, доцент, \\ докторант \\ Львівського університету бізнесу та права
}

\title{
МІСЦЕ ПРАВА ОСОБИ НА ОХОРОНУ ЗДОРОВ'Я В СИСТЕМІ ПРАВ ЛЮДИНИ
}

Постановка проблеми. Право на охорону здоров'я займає особливе місце у системі інших конституційних прав, оскільки інтегрує у собі ознаки як соціальних, економічних, такі і культурних прав. Його пов'язаність з іншими правами зумовлена також особливістю об'єкта, яким виступають здоров'я й охорона здоров'я, що одночасно є складовими елементами об'єктів деяких інших прав. Тому комплексний підхід у сфері дослідження права на охорону здоров'я дозволяє виявити взаємний вплив різних видів соціальних, економічних і культурних прав, їх співвідношення та критерії розмежування.

Водночас право на охорону здоров'я є самостійним конституційним правом, у зв'язку з чим виникає необхідність у визначенні його місця у системі інших прав, з'ясування його специфічного значення та ролі.

Стан дослідження. Питання систематизації конституційних прав, у т. ч. визначення співвідношення деяких конституційних прав між собою, досліджували такі науковці, як Ю.М. Бисага, В.С. Віткова, О.М. Волкова, В.Ф. Москаленко, Я.Ф. Радиш, І.Я. Сенюта, Ю.О. Сульженко, О.М. Ціборовський та ін. Проте слід зауважити, що комплексних наукових робіт, присвячених проблемі визначення місця права на охорону здоров'я у системі інших конституційних прав, у вітчизняній науці конституційного права не достатньо, що зумовлює актуальність пропонованої теми.

Метою статті є проведення системного науково-правового аналізу співвідношення права на охорону здоров'я з іншими правами та визначення його місця в системі таких прав.

Виклад основного матеріалу. Право на охорону здоров'я визначається у ст. 49 Конституції України [1] та належить до групи соціально-економічних прав. Тому, досліджуючи співвідношення права на охорону здоров'я з іншими конституційними правами, передусім варто звернути увагу на традиційну класифікацію прав людини і громадянина, прийняту у правовій теорії.

Так, у науковій літературі зазначається, що, оскільки основні права і свободи людини та громадянина забезпечують політичну, соціальну, економічну і культурну сфери життєдіяльності, то, відповідно, таке розмежування спричинило поділ основних прав і свобод людини та громадянина за категоріями та найменуваннями [2, с. 21].

3 цього приводу, однак, необхідно зауважити, що на сучасному етапі розвитку конституційних прав складно провести чітке розмежування групи соціальних, економічних, культурних прав одна від одної. Така ситуація зумовлена тим, що означені сфери життєдіяльності тісно пов'язані між собою, а реалізація, скажімо, соціального статусу особи не може бути здійснена ізольовано від задоволення її економічних або культурних потреб.

На думку О.М. Волкової, той факт, що в теорії держави і права соціальні права часто поєднуються з економічними та культурними, не можна вважати позитивною тенденцією. Проблема розмежування соціальних прав, з однієї сторони, й економічних і культурних - з іншої, ускладнена, як вважає науковець, традиційно прийнятою у нашій державі концепцією їх єдиного розуміння [3, с. 41].

Порушену проблему можна розглядати лише у науковому ракурсі для того, щоб визначити науково-обгрунтовані межі різних груп прав, оскільки розмежування соціальних, економічних i культурних прав має не стільки практичне, скільки науково-теоретичне значення. Тим більше, що Конституція України не надає пріоритетного значення тій чи іншій групі прав, не виділяє головні та похідні права - всі права визнаються однаково важливими та рівною мірою гарантуються державою.

У зв'язку з цим більш правильним видається системний підхід, який, на думку деяких науковців, дозволяє повніше, контрастніше виявити найбільш істотні кореляційні, субординаційні та інші зв'язки та відносини між цілим і його частинами, а також останніх між собою. Тому інтегративний підхід до прав людини, як вважає 0.О. Отставнова, є єдино правильним. Виходячи з цього, вчена зазначає, що право на охорону здоров'я та медичну допомогу знаходиться в загальній системі конституційно-правового регулювання, з чого випливає, що конституційні права і свободи людини та громадянина повинні співіснувати, взаємно доповнюючи один одного [4, с. 40]. Отже, саме системний підхід дозволить з'ясувати взаємозв'язки між соціальними, економічними, культурними та іншими правами та, зокрема, визначити місце у їх системі права на охорону здоров'я. 
Необхідно погодитися з думкою О.М. Ціборовського, який зазначає, що, оскільки здоров'я $\epsilon$ найбільшою суспільною та індивідуальною цінністю, значною мірою впливає на процеси і результати економічного, соціального та культурного розвитку країни, демографічну ситуацію і стан національної безпеки, а також є важливим соціальним критерієм ступеня розвитку і благополуччя суспільства, проблеми охорони здоров'я вимагають постійної уваги держави, а їх розв'язання має бути одним із пріоритетних напрямів соціальної політики [5, с. 4].

Взаємозумовленість і тісний зв'язок права на охорону здоров'я з іншими соціально-економічними та культурними правами викликаний передусім тим, що досліджуване право має досить широкий зміст, а також спільні з іншими правами елементи у структурі свого об'єкта.

Зокрема, відповідно до ст. 6 Основ законодавства України про охорону здоров'я кожний громадянин України має право на охорону здоров'я, що передбачає:

а) життєвий рівень, включаючи їжу, одяг, житло, медичний догляд і соціальне обслуговування і забезпечення, який є необхідним для підтримання здоров'я людини;

б) безпечне для життя і здоров'я навколишне природне середовище;

в) санітарно-епідемічне благополуччя теритоpiї та населеного пункту, де він проживає;

г) безпечні та здорові умови праці, навчання, побуту і відпочинку;

д) кваліфіковану медичну допомогу, включаючи вільний вибір лікаря, вибір методів лікування відповідно до його рекомендацій і закладу охорони здоров'я тощо [6].

Отже, як показує аналіз наведеної норми, у законодавстві чітко визначено, що деякі з гарантованих Конституцією України прав входять до змісту права на охорону здоров'я. Тому можна зробити попередній висновок про те, що право на охорону здоров'я $€$ ширшим за деякі інші конституційні права, зокрема такі, як право на достатній життєвий рівень, на безпечне для життя навколишне середовище та ін. Водночас право на охорону здоров'я необхідно вважати невід'ємною складовою частиною права на життя.

$\mathrm{y}$ науковій літературі висловлюються різні думки із приводу визначення місця права на охорону здоров'я у системі інших конституційних прав.

У свою чергу, I.Я. Сенюта вважає, що право людини на охорону здоров'я як суб'єктивне юридичне явище, з одного боку, виконує гарантійну функцію щодо інших суб'єктивних юридичних прав (наприклад, щодо права на життя, права на особисту недоторканність), а з іншого - своїми гарантіями має інші суб'єктивні юридичні права (наприклад, право на інформацію, право на соці- альний захист), а окрім того, сама охорона здоров'я є підставою обмеження інших суб'єктивних юридичних прав людини [7, с. 189].

Інші вчені зауважують, що деякі соціальні та політичні права, покликані захищати людину, тісно пов'язані з охороною здоров'я - це право на життя, заборона тортур. 3 іншого боку, ряд економічних і соціальних прав включає в себе питання охорони здоров'я, в т. ч. право на житло і право на освіту. Найбільше у змісті права на охорону здоров'я потрапляє ряд правомочностей, що входять до змісту права на життя, права на особисту недоторканність, права на освіту та інформацію, права на працю [4, с. 46].

Таким чином, за своїм змістом право на охорону здоров'я співвідноситься 3 деякими іншими конституційними правами (на безпечні умови праці, безпечне довкілля та ін.) як мета та засіб її досягнення, тобто для збереження здоров'я населення мають бути забезпечені інші права.

Необхідно більш детально розглянути сутнісне співвідношення права на охорону здоров'я 3 деякими іншими конституційними правами, які пов'язані спільними елементами у структурі об'єкта або є взаємозумовленими. Зокрема, право на охорону здоров'я має особливий зв'язок із такими правами.

1. Право на життя. Так, відповідно до ст. 27 Конституції України кожна людина має невід'ємне право на життя.

Видатний дослідник конституційного права Ю.М. Бисага справедливо зазначає, що право на життя - одне 3 найдорожчих прав, невід'ємна цінність кожної людини. Воно дозволяе людині володіти всіма правами та свободами. До того ж, життя - право, яке не можна оновлювати, тому захист права на життя належить до найважливіших пріоритетів [8, с. 33].

Погоджуючись із думкою науковця, необхідно також зауважити, що зі змісту ст. 3 Конституції України випливає, що життя і здоров'я, честь і гідність, недоторканність і безпека людини поставлені на один рівень і визнаються в Україні найвищою соціальною цінністю. У зв'язку з цим право на життя та право на охорону здоров'я належать до однієї групи прав, хоча їхній зміст складають також інші правомочності.

Деякі науковці вбачають співвідношення права на життя та права на охорону здоров'я у такому: право на охорону здоров'я виступає однією з гарантій права на життя з огляду на те, що право на життя є визначальним у системі прав людини, а здоров'я людини є одним із головних критеріїв повноцінного життя, умовою «якості життя». Питання, пов'язані з евтаназією, діяльністю хоспісів як альтернативного розв'язання проблем невиліковно хворих людей - одні з визначальних як при дослідженні права на життя, так і при досліджен- 
ні права на охорону здоров'я. I саме вони створюють «спільну територію» дослідження, що дає підставу обговорювати співвідношення згаданих вище прав [7, с. 189].

Отже, право на життя включає в себе і право на охорону здоров'я, оскільки реалізація першого права не можлива без створення умов для підтримання здоров'я на належному рівні. Водночас як право на охорону здоров'я, так і право на життя мають поряд зі спільними елементами об'єкта (здоров'я, повноцінне життя та ін.) деякі відмінності. Зокрема, такі правомочності, як вільний вибір лікаря, вибір методів лікування, медичне страхування є об'єктом права на охорону здоров'я, однак їх складно віднести до змісту права на життя. Таким чином, можна зробити висновок, що досліджувані конституційні права мають спільні та відмінні елементи у структурі об’єктів, і одночасно з цим право на життя є ширшим, оскільки частково поглинає у собі деякі правомочності, що входять до змісту права на охорону здоров' я - отримання кваліфікованої медичної допомоги, у т. ч. безкоштовної, у державних і комунальних закладах охорони здоров'я, епідеміологічне благополуччя тощо.

2. Право на повагу до гідності, яке відповідно до ст. 28 Конституції України тлумачиться так, що ніхто не може бути підданий катуванню, жорстокому, нелюдському або такому, що принижує його гідність, поводженню чи покаранню. Також встановлено, що жодна людина без її вільної згоди не може бути піддана медичним, науковим чи іншим дослідам.

У свою чергу, захист від катування, нелюдського поводження є однією з гарантій захисту здоров'я особи, яка реалізується шляхом незавдання шкоди психічному та фізичному здоров'ю особи за будь-яких умов, незалежно від статусу, місця перебування людини тощо. Отже, гарантований Конституцією України захист від катування та нелюдського поводження виступає одним із видів забезпечення охорони здоров'я (попередження завдання фізичної або психічної шкоди здоров'ю).

3. Право на працю та відпочинок. Право на працю визначене у ст. 43 Конституції України, де зазначається, що кожен має право на працю, яке включає можливість заробляти собі на життя працею, котру людина вільно обирає або на яку вільно погоджується. Крім того, у цій нормі встановлюється заборона на використання примусової праці, а також праці жінок і неповнолітніх на небезпечних для їхнього здоров'я роботах.

Взаємозв'язок цього права із правом на охорону здоров'я виражається у такому: по-перше, підтримання здоров' я на належному рівні передбачає наявність фінансових і фактичних можливостей для цього, чому певною мірою сприяє гарантована державою оплачувана зайнятість; по-друге, охо- рона здоров'я також забезпечується створенням безпечних і здорових умов праці; по-третє, в особливому порядку держава піклується про охорону здоров'я окремих категорій громадян, зокрема жінок і дітей, що виявляється, крім іншого, у забороні використання їх праці на роботах із важкими та шкідливими умовами праці.

Відповідно до ст. 45 Конституції України кожен, хто працює, має право на відпочинок. Це право забезпечується наданням днів щотижневого відпочинку, а також оплачуваної щорічної відпустки, встановленням скороченого робочого дня щодо окремих професій і виробництв, скороченої тривалості роботи у нічний час.

Таким чином, право на відпочинок певним чином зумовлює забезпечення охорони здоров'я, оскільки створює умови для профілактики та попередження захворюваності. Крім того, окремі державні гарантії одночасно забезпечують реалізацію досліджуваних видів прав (наприклад, надання оплачуваної щорічної відпустки, санаторно-курортне лікування тощо).

4. Право на соціальний захист, що включає право на забезпечення у разі повної, часткової або тимчасової втрати працездатності, втрати годувальника, безробіття з незалежних від особи обставин, а також у старості та в інших випадках, передбачених законом.

Так, за умов повної або часткової втрати працездатності право на охорону здоров'я набуває активного характеру, тобто реалізується шляхом отримання гарантованої державою медичної допомоги, у т. ч. безоплатної у державних і комунальних закладах охорони здоров'я, санаторно-курортне лікування та вжиття інших заходів, необхідних для відновлення здоров'я, відшкодування державою їх вартості за рахунок коштів фонду соціального страхування та ін.

5. Право на достатній життєвий рівень для себе і своєї сіл’ї, визначене у ст. 48 Конституції України, що включає достатнє харчування, одяг, житло.

Зв'язок цього права із правом на охорону здоров'я має переважно економічний характер i виражається у тому, що, створюючи умови для достатнього життєвого рівня своїх громадян та інших осіб, держава тим самим піклується про підтримання належного рівня громадського здоров'я (завдяки нормальному харчуванню, належним житловим і гігієнічним умовам тощо). Отже, реалізація права на охорону здоров'я тісно пов'язане з реалізацією права на достатній життєвий рівень.

6. Право на безпечне для життя $і$ здоров'я довкілля та на відшкодування завданої порушеннял иього права шкоди. Відповідно до ст. 50 Конституції України кожному гарантується право вільного доступу до інформації про стан довкілля, про якість харчових продуктів і предметів побуту, 
а також право на їі поширення. Така інформація ніким не може бути засекречена.

Одним із обов'язків держави є забезпечення екологічного благополуччя у державі, яке прямо впливає на стан громадського здоров'я. Заборона засекречування інформації про стан довкілля, якість харчових продуктів пов'язана з тим, що така інформація може виявитися життєво важливим чинником, необхідним для вжиття відповідних профілактичних, лікувальних та інших заходів, спрямованих на охорону (відновлення) здоров'я. Тобто це право за своєю сутністю є своєрідною гарантією забезпечення реалізації права на охорону здоров'я.

Таким чином, на підставі проведеного дослідження можна зробити висновок, що соціальні, економічні, культурні та інші конституційні права тісно пов'язані між собою, є взаємозумовленими та певним чином перетинаються за змістом. Тому за сучасних умов необхідне їх комплексне дослідження, що передбачає застосування передусім системного методу. Водночас право на охорону здоров'я необхідно визнати самостійним конституційним правом, оскільки у його зміст включено такі правомочності, які у системі створюють єдиний унікальний об'єкт цього права, що дозволяє говорити про його сутнісну особливість. Остання виражається у тому, що право на охорону здоров'я поєднує у собі елементи соціальних, економічних і культурних прав, а отже, його реалізація потребує відповідних видів гарантій.

У зв'язку з цим можна говорити про те, що значення права на охорону здоров'я у системі інших конституційних прав полягає у тому, що завдяки його реалізації створюються гарантії для здійснення деяких інших прав (зокрема, права на життя, на працю). Одночасно з цим його реалізація потребує створення певних передумов, якими можуть виступати такі права, як право на достатній життєвий рівень, екологічне благополуччя тощо.

\section{Jimepamypa}

1. Конституція України від 28 червня $1996 \mathrm{p}$ № 254к/96-BP. URL: http://zakon3.rada.gov.ua/laws/ show $/ 254 \%$ D0 $\%$ BA $/ 96-\%$ D0 $\%$ B2 $\%$ D1 $\% 80$.

2. Сульженко Ю.О. Конституційний генезис захисту економічних прав та свобод людини і громадянина у світі та Україні. Юридична наука. 2011. № 4-5. C. 16-23.

3. Волкова О.М. Соціальні права особи: поняття, сутність, особливості. Часопис Київського університету права. 2011. № 1. С. 39-43.
4. Отставнова Е.А. Конституционные основы защиты права человека и гражданина на охрану здоровья и медицинскую помощь в современной России : дисс. ... канд. юрид наук : 12.00.02. Саратов. 2010. 246 с.

5. Ціборовський O.М., Істомін С.В., Сорока В.М. Шляхи систематизації законодавства України у сфері охорони здоров'я. Київ, 2011. 72 с.

6. Основи законодавства України про охорону здоров'я : Закон України від 19 листопада 1992 р. № 2801-XII. URL:http://zakon3.rada.gov.ua/laws/show/ 2801-12.

7. Сенюта I.Я. Право людини на охорону здоров’я та його законодавче забезпечення в Україні : дис. ... канд. юрид. наук : 12.00.01. Львів, 2006. 215 с.

8. Права людини / Бисага Ю.М., Палінчак М.М., Бєлов Д.М., Данканич М.М. Ужгород, 2003. 189 с.

\section{Анотація}

Швець Ю. Ю. Місце права особи на охорону здоров'я в системі прав людини. - Стаття.

Стаття присвячена висвітленню проблеми співвідношення права на охорону здоров'я з іншими конституційними правами та визначенню його місця у системі таких прав. Проаналізоване змістове та сутнісне співвідношення права на охорону здоров'я з такими конституційними правами, як право на життя, рівність $і$ вільний розвиток, достатній життєвий рівень, повагу до гідності, свободу та особисту недоторканність, відпочинок тощо. На підставі проведеного аналізу зроблено висновок про місце права на охорону здоров'я у системі інших конституційних прав.

Обґрунтовано, що право на охорону здоров'я є самостійним конституційним правом, у зв'язку з чим виникає необхідність у визначенні його місця у системі інших прав, з'ясування його специфічного значення та ролі.

На підставі проведеного дослідження зроблено висновок, що соціальні, економічні, культурні та інші конституційні права тісно пов'язані між собою, є взаємозумовленими та певним чином перетинаються за змістом. Тому за сучасних умов необхідне їх комплексне дослідження, що передбачає застосування передусім системного методу. Водночас право на охорону здоров'я необхідно визнати самостійним конституційним правом, оскільки у його зміст включено такі правомочності, які у системі створюють єдиний унікальний об'єкт цього права, що дозволяє говорити про його сутнісну особливість. Остання виражається у тому, що право на охорону здоров'я поєднує у собі елементи соціальних, економічних і культурних прав, а отже, його реалізація потребує відповідних видів гарантій.

Доведено, що значення права на охорону здоров'я у системі інших конституційних прав полягає у тому, що завдяки його реалізації створюються гарантії для здійснення деяких інших прав (зокрема права на життя, на працю). Одночасно з цим його реалізація потребує створення певних передумов, якими можуть виступати такі права, як право на достатній життєвий рівень, екологічне благополуччя тощо.

Ключові слова: право на охорону здоров'я, адміністративні права, співвідношення. 


\section{Summary}

Shvets $Y u$. Yu. The problem of correlation of the right to health care with other constitutional rights. - Article.

The article is devoted to the problem of correlation of the right to health care with other constitutional rights and to determine its place in the system of such rights. The meaningful and essential correlation of the right to health care with such constitutional rights as the right to life, equality and free development, sufficient standard of living, respect for dignity, freedom and personal inviolability, rest, etc. is analyzed. Based on the analysis, a conclusion was made about the place of the right to health care in the system of other constitutional rights.

It is substantiated that the right to health care is an independent constitutional right, in connection with which there is a need to determine its place in the system of other rights, to clarify its specific meaning and role.

Based on the study, it was concluded that social, economic, cultural and other constitutional rights are closely interrelated, interdependent and in some ways intersect in content. Therefore, in modern conditions, they need a comprehensive study, which involves the use of primarily systemic method. However, the right to health care must be recognized as an independent constitutional right, as its content includes such powers that create a single unique object of this right in the system, which allows us to speak about its essential feature. The latter is expressed in the fact that the right to health care combines elements of social, economic and cultural rights, and therefore its implementation requires appropriate types of guarantees.

It has been proven that the importance of the right to health care in the system of other constitutional rights lies in the fact that its implementation creates guarantees for the exercise of certain other rights (in particular, the right to life and work). At the same time, its implementation requires the creation of certain preconditions, which can be such rights as the right to an adequate standard of living, environmental well-being and so on. ratio.

Key words: right to health care, administrative rights, 